\title{
MICROHABITAT USE BY GREY JUNGLEFOWL (GALLUS SONNERATII) AT THENI FOREST DIVISION, WESTERN GHATS OF TAMIL NADU, SOUTH INDIA
}

\author{
C. SUBRAMANIAN ${ }^{1} *-$ C. RAMESH KUMAR ${ }^{2}-$ M.C.SATHYANARAYANA ${ }^{2}$ \\ ${ }^{I}$ Department of Biology, Eritrean Institute of Technology, \\ Mainefhi, The State of Eritrea, North-east Africa \\ ${ }^{2}$ Division of Wildlife Biology, A.V.C.College (Autonomous) Mayiladuthurai, India \\ *Corresponding author \\ e-mail: csubramanian24@yahoo.co.in \\ (Received $28^{\text {th }}$ August 2007; accepted $20^{\text {th }}$ February 2008 )
}

\begin{abstract}
The overall results showed 64\% of Grey Junglefowl sightings in $<40 \%$ canopy cover category. The results indicated that majority of the sightings (77\%) was in $>41 \%$ shrub cover category. Use of litter cover categories was $(67 \%)$ in $<40 \%$ and the use of litter depth was in $<4 \mathrm{~cm}$ litter category. The $67 \%$ sightings were obtained in $<4$ tree number category.
\end{abstract}

Keywords: Habitat use; Grey Junglefowl; Western Ghats

\section{Introduction}

The habitat use is a critical facet in the management of wildlife species [1]. Habitat provides food and cover essential for the population to survive. Central to the study of animal ecology is the usage an animal makes of its environment: specifically, the kinds of food it consumes and the varieties of habitats it occupies [2]. Many analytic procedures have been devised to treat data on the usage of such resources, particularly in relation to information on their availability to the animal, for the purpose of determining "preference".

Attempts always go beyond simple documentation of habitat use to determine if specific habitats are selected; i.e., used more or less than availability [3]. The importance of knowing the detailed habitat requirements if want to develop an effective conservation strategy for protecting a wild game bird species [4]. A general idea of the broad biotype that a species occupies (e.g. forest, agricultural land, marshes etc) is not sufficient. We need to find how it uses habitat types within these areas and which of these are most important for its continued survival. In order to acquire this type of information detailed studies of the bird's location are required.

It is stressed the birds adapt to areas with suitable habitat, which provides nesting site, nesting material, food and protection from other species [5]. It is reported [6] that within geographical areas, species are not evenly distributed across all available habitats, but tends to use some habitats more than others. A species is found with greatest frequency and abundance in the habitats to which it is best adapted. These preferences might change across geographical areas and over seasons. Alteration and destruction of habitats by humans can have a drastic effect on some species, while others adapt to the modified habitat. Therefore data on the habitat requirements of a species could be useful for predicting the effects of habitat destruction due to humans on natural communities. This paper is the first report on habitat use by Gallus 
sonneratii due to lack of previous information on Grey Junglefowl, at Theni forest division, Western Ghats of southern India (Fig 1). The grey junglefowl is one of the endemic to south peninsular India which is vulnerable in status.

\section{Study area}

The Theni Forest Division (9 $31^{\prime}-10^{\circ} 10^{\prime}-\mathrm{N}, 77^{\circ} 20^{\prime}-77^{\circ} 40^{\prime} \mathrm{E}$ ) is located $76 \mathrm{Km}$ west of Madurai City in Theni district, Tamilnadu South India. This area forms part of the Western Ghats and it is located on the boundary of Tamilnadu and Kerala State. This forest covers an area of $723 \mathrm{~km}^{2}$. It comprises of Bodi, Cumbum, Gudalur and Meghamalai Forest Ranges.

The Theni Forest Division provides habitat for several mammals such as lion tailed macaque (Macaca silenus), common langur (Trachypithecus entellus) Nilgiri langur (Trachypithecus johnii), slender loris(Loris tardigradus), tiger (Panthera tigris), leopard (Panthera pardus), Jungle cat (Felis chaus), sloth bear (Melursus ursinus), Nilgiri marten (Martes gwatkinsi), Travancore flying squirrel (Petinomys fuscocapillus), Asian elephant (Elephas maximus), gaur (Bos gaurus), Nilgiri tahr (Hemitragus hylocris), sambar deer (Cervus unicolor), spotted deer (Axis axis), barking deer (Muntiacus muntjak), mouse deer (Tragilus meminna), and Indian wild boar (Sus scrofa). In addition to Grey Junglefowl a total of 97 bird species belonging to 15 orders and 36 families were also recorded.

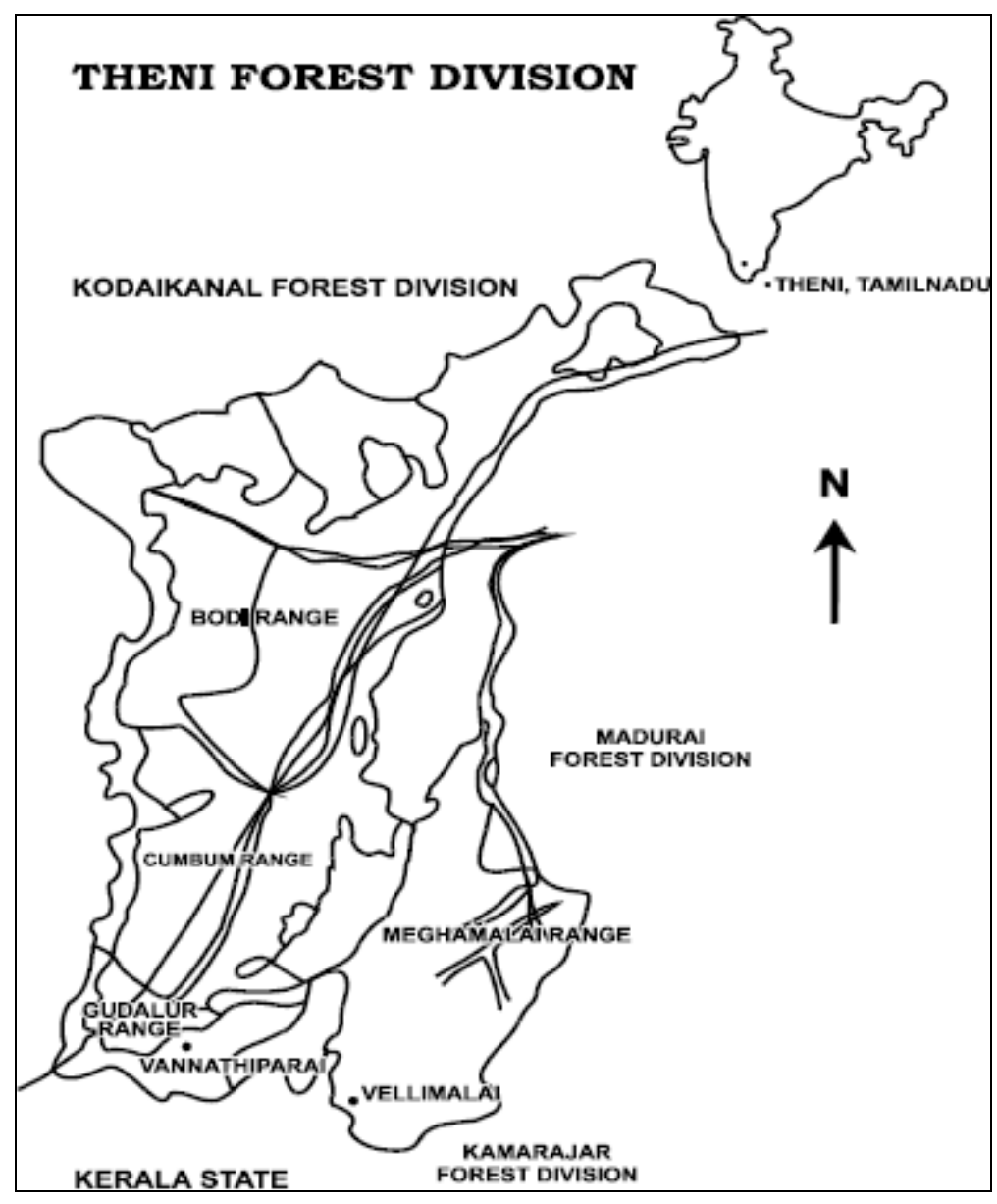

Figure 1. Map of the study area 


\section{Methods}

The habitat type and microhabitat variables used by Grey Junglefowl were recorded for all sightings obtained along the transects. For this purpose, bird focal plots (10m $\mathrm{x}$ $10 \mathrm{~m}$ ) were laid to quantify variables (the immediate environment) such as canopy cover $(\%)$ and tree numbers $(\mathrm{N})$. Within these bird focal plots, sub plots $(5 \mathrm{~m} \times 5 \mathrm{~m})$ were laid to quantify shrub cover $(\%)$ followed by laying of smaller quadrats $(1 \mathrm{~m} \mathrm{x} 1 \mathrm{~m})$ to estimate the grass cover (\%) litter cover $(\%)$ and litter depth $(\mathrm{cm})$. This method adapted by Young et al [7]. For every Grey Junglefowl sighting only on transects, the "location site" was marked as "bird focal plots" and the selected parameters were quantified. The Availability-Utilization of micro habitat variables by Grey Junglefowl was analysed by using Ivlev's [8] index of selectivity.

Ivlev's index of selectivity $=\frac{U-A}{U+A}$

Whereas $\quad \mathrm{U}=$ Used micro habitat variables

$\mathrm{A}=$ Available microhabitat variables.

\section{Results}

In order to assess the use of habitat variables such as canopy cover, shrub cover, grass cover, litter cover, litter depth and tree number, all the 88 sightings of Grey Junglefowl were taken into account. The uses of habitat variables by Grey Junglefowl in different seasons in the Study Area are given in the Table 1.

Table 1. . Use of habitat variables by Grey Junglefowl in different seasons

\begin{tabular}{|c|c|c|c|c|c|}
\hline Parameters & Post-monsoon & Summer & Pre-monsoon & Monsoon & Overall \\
\hline $\begin{array}{c}\text { Canopy } \\
\text { cover }(\%)\end{array}$ & $\mathrm{NS}$ & $\begin{array}{c}\mathrm{P}<0.01 \\
(21-40 \%) \\
\text { LOW }\end{array}$ & $\begin{array}{c}\mathrm{P}<0.05 \\
(21-40 \%) \\
\text { LOW }\end{array}$ & NS & $\begin{array}{c}\mathrm{P}<0.02 \\
(<40 \%) \\
\text { LOW }\end{array}$ \\
\hline $\begin{array}{c}\text { Shrub cover } \\
(\%)\end{array}$ & $\begin{array}{c}\mathrm{P}<0.05 \\
(41-60 \%) \\
\text { MODERATE }\end{array}$ & $\begin{array}{c}\mathrm{P}<0.01 \\
(41-60 \%) \\
\text { MODERATE }\end{array}$ & $\begin{array}{c}\mathrm{P}<0.21 \\
(41-60 \%) \\
\text { MODERATE }\end{array}$ & $\begin{array}{c}\mathrm{P}<0.001 \\
(41-60 \%) \\
\text { MODERATE }\end{array}$ & NS \\
\hline $\begin{array}{c}\text { Grass cover } \\
(\%)\end{array}$ & $\begin{array}{c}\mathrm{P}<0.01 \\
(21-40 \%) \\
\text { LOW }\end{array}$ & $\begin{array}{c}\mathrm{P}<0.001 \\
(<20 \%) \\
\text { VERY LOW }\end{array}$ & $\begin{array}{c}\mathrm{P}<0.001 \\
(21-40 \%) \\
\text { LOW }\end{array}$ & $\begin{array}{c}\mathrm{P}<0.001 \\
(21-40 \%) \\
\text { LOW }\end{array}$ & $\begin{array}{c}\mathrm{P}<0.05 \\
(<40 \%) \\
\text { LOW }\end{array}$ \\
\hline $\begin{array}{l}\text { Litter cover } \\
\qquad(\%)\end{array}$ & $\begin{array}{c}\mathrm{P}<0.20 \\
(21-40 \%) \\
\text { LOW }\end{array}$ & $\begin{array}{c}\mathrm{P}<0.01 \\
(21-40 \%) \\
\text { LOW }\end{array}$ & $\begin{array}{c}\mathrm{P}<0.02 \\
(21-40 \%) \\
\text { LOW }\end{array}$ & $\begin{array}{c}\mathrm{P}<0.02 \\
(21-40 \%) \\
\text { LOW }\end{array}$ & $\begin{array}{c}\mathrm{P}<0.01 \\
(>41 \%) \\
\text { MODERATE }\end{array}$ \\
\hline $\begin{array}{l}\text { Litter depth } \\
\quad(\mathrm{cm})\end{array}$ & $\begin{array}{c}\mathrm{P}<0.001 \\
(<4 \mathrm{~cm}) \\
\text { LOW }\end{array}$ & NS & NS & $\begin{array}{c}\mathrm{P}<0.001 \\
(<4 \mathrm{~cm}) \\
\text { LOW }\end{array}$ & $\begin{array}{c}\mathrm{P}<0.05 \\
(<4 \mathrm{~cm}) \\
\text { LOW }\end{array}$ \\
\hline $\begin{array}{l}\text { Tree number } \\
\text { (N) }\end{array}$ & $\begin{array}{c}\mathrm{P}<0.20 \\
(>4 \mathrm{~N}) \text { LOW }\end{array}$ & NS & NS & $\mathrm{NS}$ & NS \\
\hline
\end{tabular}

Chi-square test: $\mathrm{NS}=$ Not significant

The overall results indicated that majority of the Grey Junglefowl sightings were used $<40 \%$ canopy cover category, $>41 \%$ shrub cover category, $<40 \%$ grass cover 
category, $>41 \%$ litter cover category, $<4 \mathrm{~cm}$ litter depth category and $<4$ tree number in bird focal plots.

\section{Use of canopy cover}

The overall results showed $64 \%$ of Grey Junglefowl sightings in $<40 \%$ canopy cover category $\left(\chi^{2}=10.309, \mathrm{df}=3, \mathrm{P}<0.02\right)$. It was found that there were differences in the canopy cover use during all the seasons (Table 2).

Table 2. . Use of canopy cover (\%) in different seasons in the Study Area,1999-2000

\begin{tabular}{|l|c|c|c|c|c|}
\hline \multirow{2}{*}{ SEASON } & \multicolumn{2}{|c|}{$\begin{array}{c}\text { Use of canopy cover (\%) } \\
\text { Categories }\end{array}$} & \multirow{2}{*}{$\boldsymbol{\chi}^{\mathbf{2}}$} & \multirow{2}{*}{ df } & \multirow{2}{*}{ P } \\
\cline { 2 - 6 } & $\mathbf{I}$ & $\begin{array}{c}\text { II } \\
\mathbf{4 4 1} \%\end{array}$ & & & \\
\hline Post-monsoon & 57 & 43 & 0.428 & 1 & $\mathrm{P}>0.05^{*}$ \\
\hline Summer & 83 & 17 & 10.666 & 1 & $\mathrm{P}<0.01$ \\
\hline Pre-monsoon & 74 & 26 & 4.262 & 1 & $\mathrm{P}<0.05$ \\
\hline Monsoon & 42 & 58 & 0.666 & 1 & $\mathrm{P}>0.05^{*}$ \\
\hline
\end{tabular}

Chi Square test:

$\chi^{2}=10.309, \mathrm{df}=3, \mathrm{P}<0.02 ; *$ Significant

\section{Use of shrub cover}

The overall results indicated that majority of the Grey Junglefowl sightings (77\%) were in $>41 \%$ shrub cover category. It was observed that there were no differences in the shrub cover use in a season $\left(\chi^{2}=2.782, \mathrm{df}=3, \mathrm{P}>0.05\right) . \quad 88 \%$ of the Grey Junglefowl sightings in monsoon, $79 \%$ in summer, $71 \%$ in post-monsoon and $68 \%$ in pre-monsoon utilized $>41 \%$ shrub cover category (Table 3 ).

Table 3. Use of shrub cover (\%) in different seasons in the Study Area, 1999-2000

\begin{tabular}{|l|c|c|c|c|c|}
\hline \multirow{2}{*}{ SEASON } & \multicolumn{2}{|c|}{$\begin{array}{c}\text { Use of shrub cover (\%) } \\
\text { Categories }\end{array}$} & \multirow{2}{*}{$\boldsymbol{\chi}^{\mathbf{2}}$} & df & \multirow{2}{*}{ P } \\
\cline { 2 - 6 } & $\begin{array}{c}\text { I } \\
<\mathbf{4 0} \%\end{array}$ & $\begin{array}{c}\text { II } \\
\mathbf{4 4 1} \%\end{array}$ & & & \\
\hline Post-monsoon & 29 & 71 & 3.856 & 1 & $\mathrm{P}<0.05$ \\
\hline Summer & 21 & 79 & 8.166 & 1 & $\mathrm{P}<0.01$ \\
\hline Pre-monsoon & 32 & 68 & 2.578 & 1 & $\mathrm{P}<0.20$ \\
\hline Monsoon & 12 & 88 & 13.5 & 1 & $\mathrm{P}<0.001$ \\
\hline
\end{tabular}

Chi Square test: $\chi^{2}=2.782, \mathrm{df}=3, \mathrm{P}>0.05$ 


\section{Use of grass cover}

About $93 \%$ sightings of Grey Junglefowl was in $<40 \%$ grass cover category (Table 4). There was a significant difference in the use of grass cover across the seasons $\left(\chi^{2}=9.366, \mathrm{df}=3, \mathrm{P}<0.05\right)$.

Table 4. Use of grass cover (\%) in different seasons in the Study Area, 1999-2000

\begin{tabular}{|l|c|c|c|c|c|}
\hline \multirow{2}{*}{ SEASON } & \multicolumn{2}{|c|}{$\begin{array}{c}\text { Use of grass cover }(\%) \\
\text { Categories }\end{array}$} & \multirow{2}{*}{$\boldsymbol{\chi}^{\mathbf{2}}$} & \multirow{2}{*}{ df } & \multirow{2}{*}{ P } \\
\cline { 2 - 4 } & $\begin{array}{c}\text { I } \\
\mathbf{4 4 0} \%\end{array}$ & $\begin{array}{c}\text { II } \\
\mathbf{4 4 1} \%\end{array}$ & & & \\
\hline Post-monsoon & 81 & 19 & 8.046 & 1 & $\mathrm{P}<0.01$ \\
\hline Summer & 100 & 0 & 24 & 1 & $\mathrm{P}<0.001$ \\
\hline Pre-monsoon & 100 & 0 & 19 & 1 & $\mathrm{P}<0.001$ \\
\hline Monsoon & 92 & 8 & 16.666 & 1 & $\mathrm{P}<0.001$ \\
\hline
\end{tabular}

Chi Square test: $\chi^{2}=9.366, \mathrm{df}=3, \mathrm{P}<0.0 .5$

\section{Use of litter cover}

The overall results indicated that $67 \%$ of Grey Junglefowl sightings were in the $>41 \%$ litter cover category and this was statistically significant $\left(\chi^{2}=14.666, \mathrm{df}=3\right.$, $\mathrm{P}<0.01)$. It was found that there were differences in the litter cover use during all the seasons (Table 5).

Table 5. Use of litter cover (\%) in different seasons in the Study Area, 1999-2000

\begin{tabular}{|l|c|c|c|c|c|}
\hline \multirow{2}{*}{ SEASON } & \multicolumn{2}{|c|}{$\begin{array}{c}\text { Use of litter cover (\%) } \\
\text { Categories }\end{array}$} & \multirow{2}{*}{$\boldsymbol{\chi}^{\mathbf{2}}$} & \multirow{2}{*}{ df } & \multirow{2}{*}{ P } \\
\cline { 2 - 3 } & $\begin{array}{c}\text { I } \\
<\mathbf{4 0} \%\end{array}$ & $\begin{array}{c}\text { II } \\
\mathbf{4 4 1} \%\end{array}$ & & & \\
\hline Post-monsoon & 67 & 33 & 2.541 & 1 & $\mathrm{P}>0.20$ \\
\hline Summer & 21 & 79 & 8.166 & 1 & $\mathrm{P}<0.01^{*}$ \\
\hline Pre-monsoon & 21 & 79 & 6.368 & 1 & $\mathrm{P}<0.02 *$ \\
\hline Monsoon & 25 & 75 & 6 & 1 & $\mathrm{P}<0.02 *$ \\
\hline
\end{tabular}

Chi Square test: $\chi^{2}=14.333, \mathrm{df}=3, \mathrm{P}<0.01 ; *$ Significant

\section{Use of litter depth}

The overall results revealed that a majority of Grey Junglefowl sightings (75\%) were in $<4 \mathrm{~cm}$ litter depth category (Table 6). It is observed that there were differences in the litter depth use between seasons $\left(\chi^{2}=23.536, \mathrm{df}=3, \mathrm{P}<0.05\right)$. 
Table 6. Use of litter depth $(\mathrm{cm})$ in different seasons

\begin{tabular}{|l|c|c|c|c|c|}
\hline \multirow{2}{*}{ SEASON } & \multicolumn{2}{|c|}{$\begin{array}{c}\text { Use of litter depth }(\mathbf{c m}) \\
\text { Categories }\end{array}$} & \multirow{2}{*}{$\boldsymbol{\chi}^{\mathbf{2}}$} & \multirow{2}{*}{ df } & \multirow{2}{*}{ P } \\
\cline { 2 - 3 } & $\begin{array}{c}\text { I } \\
\mathbf{4} \mathbf{~ c m}\end{array}$ & $\begin{array}{c}\text { II } \\
\mathbf{5} \mathbf{~ c m}\end{array}$ & & & \\
\hline Post-monsoon & 86 & 14 & 10.714 & 1 & $\mathrm{P}<0.001^{*}$ \\
\hline Summer & 42 & 58 & 0.666 & 1 & $\mathrm{P}>0.05$ \\
\hline Pre-monsoon & 73 & 27 & 4.262 & 1 & $\mathrm{P}<0.20^{*}$ \\
\hline Monsoon & 100 & 0 & 24 & 1 & $\mathrm{P}<0.001$ \\
\hline
\end{tabular}

Chi Square test: $\chi^{2}=23.536, \mathrm{df}=3, \mathrm{P}<0.05$; * Significant

\section{Use of trees (number)}

The overall results showed that the Grey Junglefowl sightings were obtained in $<4$ trees (in bird focal plots) number category $\left(\chi^{2}=1.14, \mathrm{df}=3, \mathrm{P}>0.05\right)$ which was not significant (Table 7).

Table 7. Use of tree number in different seasons in the Study Area, 1999-2000

\begin{tabular}{|l|c|c|c|c|c|}
\hline \multirow{2}{*}{ SEASON } & \multicolumn{2}{|c|}{$\begin{array}{c}\text { Use of tree number } \\
\text { Categories }\end{array}$} & \multirow{2}{*}{$\chi^{\mathbf{2}}$} & df & \multirow{2}{*}{ P } \\
\cline { 2 - 4 } & $\begin{array}{c}\text { I } \\
\mathbf{4} \mathbf{~ n}\end{array}$ & $\begin{array}{c}\text { II } \\
\mathbf{5 5} \mathbf{~ n}\end{array}$ & & & \\
\hline Post-monsoon & 67 & 33 & 2.332 & 1 & $\mathrm{P}<0.02 *$ \\
\hline Summer & 54 & 46 & 0.166 & 1 & $\mathrm{P}>0.05$ \\
\hline Pre-monsoon & 53 & 47 & 0.052 & 1 & $\mathrm{P}>0.05$ \\
\hline Monsoon & 62 & 38 & 1.5 & 1 & $\mathrm{P}>0.05$ \\
\hline
\end{tabular}

\section{Discussion}

The Grey Junglefowl appears that canopy cover and tree number do not have any direct significant influence on Grey Junglefowl habitat use. The result indicates that choice of habitat by Grey Junglefowl largely depends on the interspersion of moderate shrub cover $(41-60 \%)$, high litter cover $(>41 \%)$ low litter depth $(<4 \mathrm{~cm})$ and low grass cover $(<40 \%)$. Though [9] recorded Cheer in a variety of forest types, they showed a strong preference for open areas with dense ground cover. Moreover, Cheer inhabited mainly open areas with few trees and saplings, dense cover of tall grass and moderate shrub cover.

It was primarily because the shrub layer provides protection from predators (escape cover) and shade, while litter and grass or herb layers determined the invertebrate abundance, which are food items of Grey Junglefowl. The Grey Junglefowl at northwestern parts of the Bori Wildlife Sanctuary, Madyapradesh, preferred. 0-25\% cover in woods, shrubs and grass lands [10]. 
The observation [11] showed that the Kalij used mostly the 1-25\% tree cover and 26$50 \%$ category; Monal used mostly the $1-25 \%$ tree cover and $0 \%$ category. The $26-50 \%$ shrub cover category was used mostly by Kalij and the $1-25 \%$ and $0 \%$ shrub cover category by Monal. Kalij mostly used the $1-25 \%$ grass cover category and Monal the 26-50\% grass cover category.

According to report [12] Cheer showed significantly preferred areas with no or little cover. Tall and dense vegetation, both at ground level and also at shrub level were significantly avoided. The study concluded that within major plant associations Tragopans consistently selected areas for dense shrub and short deciduous life forms within the major plant associations in north eastern Pakistan [13].

It opined that a tall and dense layer provides visual cover, escape cover, and food for Lady Amherst pheasants [14]. The used plots had greater litter may provide an important foraging substrate for Lady Amherst pheasants. Low grass and herb cover probably result from the high canopy closure at organism used plots. Ring-necked pheasants selected areas near woodland and rich in food resources, with less ground cover, more shrubs and canopy. Probably, both food abundance and cover were important in habitat selection before the nesting season [15]. It [16] opined that in winter, cover becomes more important as protection from predator and woods, wetlands are selected more often.

Acknowledgements. We express our gratitude to the Ministry of Environment Govt. of India, New Delhi, for providing financial assistance and the Chief Conservator of Forest, Tamil Nadu Forest Department, Chennai for having given us permission to take up our studies at Theni Forest Division. We express our gratitude to Dr.V. Radhakrishnan, Principal and Prof. S. Swetharanyam, HOD, Division of Wildlife Biology, AVC College (Autonomous), Mayiladuthurai for their constant encouragement.

\section{REFERENCES}

[1] White, G.C., Garrot, R.A. (1990): Habitat analysis. - In: Analysis of Wildlife Radiotracking data. Academic Press, London. pp 183-204 .

[2] Johnson, D.H. (1980): The comparison of usage and Availability measurements for evaluating resource preference. - Ecology 61 (1): 65-71.

[3] Alldredge, R.J. (1986): Comparison of some statistical techniques for analysis of resource selection. - Journal of Wildlife Management 50 (1): 157-165.

[4] Dowell, S.D., Abischer Robertson, P.A. (1993): Analysing habitat use from radiotracking data - In: Jenkins, D. (ed) Pheasants in Asia 1992. World Pheasant Association Reading, UK. pp 62-66.

[5] Cody, M.L.( 1980): Species packing in insectivorous bird community: density, diversity and productivity. - Proceedings of international ornithological congress XVII: 10711077.

[6] Crowell, L.L. (1962): Reduced inter specific competition among birds of Bermuda. Ecology 43:75-88.

[7] Young, L., Zheng, G.M., Zhang Z.W. (1991): Winter movements and habitat use by Cabot`s Tragopans Tragopan caboti in Southeastern China. - Ibis133: 121-126.

[8] Ivlev, V.S. (1981): Ivlev`s index of selectivity in Experimental Ecology of feeding on herbivores. - Yale University Press, London.

[9] Kalsi, R.S. (2001): Status and Habitat of Cheer Pheasant in Himachal Pradesh, IndiaResults of 1997-1998 surveys. - Tragopan 13/14:20-26.

[10] Tata, R., Gautam, P. (1992): Habitat utilization by Grey Junglefowl in Bori Wildlife Sanctuary, India. - Journal of World Pheasant Association XVII \& XVIII: 9. 
[11] Sathyakumar, S., Prasad,. S.N, Rawat, G.S. (1993): Ecology of Kalij and Monal pheasants in Kedarnath Wildlife Sanctuary, Western Himalaya. - In: Jenkins, D. (ed.) Pheasants in Asia 1992. World Pheasant Association, Reading, UK. pp 83-90.

[12] Kaul, R. (1993): Habitat utilization by Cheer Pheasant. - In: Jenkins, D. (ed) Pheasants in Asia 1992. World Pheasant Association, Reading, UK. pp 157.

[13] Islam, K., Crawford, J.A. (1987): Habitat use by western Tragopan Tragopan melanocephalus (Gray) in Northeast Pakistan. - Biological conservation. 40:101-115.

[14] Bland, J.D., Lianxian, H. (1993): Unintentional maintenance of Lady Amherst Pheasant habitats in Rural Yunnan. - In: Jenkins, D. (ed) Pheasants in Asia 1992. World Pheasant Association, Reading, U.K. pp 134-136.

[15] Zhang, Z.W., Niu, F., Sun, Q. (1993): Ecology of the Chinese Ring-necked Pheasant. In: Jenkins D, (ed.) Pheasants in Asia 1992. World Pheasant Association, Reading, UK. pp 91-94.

[16] Hill, D.A., Robertson, P.A. (1988): The pheasant: ecology, management and conservation - BSP Professional Books. pp 281. 